(7) As to the influence of nitrogen source, the following relations were found :

For cellulose fermentation;

peptone $>$ egg albumin $>$ casein $>$ ammoniun sulfate $>$ meat extract.

For volatile acid production;

meat extract $>$ egg albumin $>$ peptone $>$ casein $>$ ammonium sulfate.

For alcoholic production;

meat extract $>$ peptone $>$ egg albumin $>$ casein $>$ ammonium sulfate.

Thus the organism seems to require the organic nitrogen for both production of volatile acid and alcohol.

(8) In the medium which contains $\mathrm{CaCO}_{3}, 64 \%$ cellulose fermented on the third day while only $32 \%$, without $\mathrm{CaCO}_{3}$ : on the seventh day, $88 \%$ fermented in the former and $46 \%$ in the latter. The production of both the volatile acid and alcohol is greatest on the third day. Such marked difference of fermentation seems to be due to the accumulation of organic acid which interferes with the process where no $\mathrm{CaCO}_{3}$ is present. Again on this basis, it is possible to follow the physiological activity of the organism by determining the $\mathrm{pH}$ values.

STUDIES ON BACILLUS THERMOFIBRINCOLUS N. SP. VI. NITROGEN METABOLISM.

By

\author{
Arao Itano and Satiyo Arakawa
}

(Received Jan, 20 th., 1930).

The action of the organism as to the transformation of amino and ammonia nitrogen in the culture medium with and without an addition of cellulose.

The results are shown in the following figure; Fig. I.

As Fig. I. indicates, in presence of cellulose, the quantity of ammonia nitrogen produced is irregular while the amino nitrogen increased steadily. In case no cellulose is present, both ammonia and amino nitrogen decreased after certain days. Consequently in presence of cellulose, the quantity of amino acid can serve as an approximate index of proteolysis, and it seems to 
indicate that the organism contains the proteolytic enzyme. This confirms the experimental results obtained by De Bord.

Fig. I.

Nitrogen Metabolism.

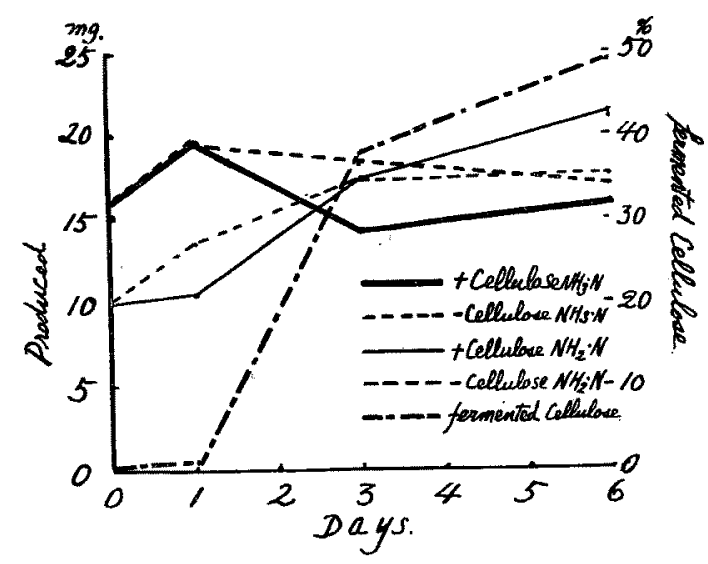

\title{
UEBER DAS VORKOMMEN VON SCHWEFLIGER SAEURE IN VERGOERENER FLUESSIGKEIT.
}

\author{
Von \\ Mosuke Matsurama und Hirotoht Nakamúra \\ (Aws dem Laboratorium der Union-Brawerei bei Tokyo, Japan.) \\ (Angenommen Jan, 25, 1930).
}

Obgleich wir in der vorhandenen Literatur mehrfach ueber Versuche mit Schwefelwasserstoff in vergorener Fluessigkeit gelesen haben, haben wir bisher nichts gefunden ueber die schweflige Saeure, die auch stets in kleinen Mengen in vergorener Fluessigkeit, z.B. in Bier und Wein, enthalten ist. Wir haben Untersuchungen auf diesem Gebiet angestellt und teilen die Resultate in folgendem mit :

Nach einigen Vorversuchen wiesen wir das Vorhandensein von schwefliger Saeure wie folgt nach: 